\title{
Assessment of genetic variability and character association in okra genotypes for yield and contributing characters
}

\author{
Meenakshi Kumari ${ }^{1}$, S. S. Solankey ${ }^{*}$, Shirin Akhtar ${ }^{1}$ and Pallavi Neha ${ }^{2}$ \\ ${ }^{1}$ Department of Horticulture (Vegetable and Floriculture), Bihar Agricultural University, Sabour - 813210 (Bihar), \\ INDIA \\ ${ }^{2}$ Department of Division of Food Science and Postharvest Technology, Indian Institute of Horticultural Research, \\ Hessaraghatta, Bangalore - 560089 (Karnataka), INDIA \\ *Corresponding author E-mail: shashank.hort@gmail.com
}

Received: December 16, 2016; Revised received: April 10, 2017; Accepted: August 25, 2017

\begin{abstract}
A study of genetic diversity in 20 okra genotypes for 22 morphological and agronomic traits (13 quantitative and 9 qualitative) was laid out in randomized block design with three replications during 2015-16. The phenotypic and genotypic variances, phenotypic (PCV) and genotypic coefficients of variation (GCV), heritability, genetic advance of the characters were studied. The genotypes demonstrated wide range of variability for all characters. In this study PCV was higher than its corresponding GCV thus revealing the role of environmental factors. High heritability $\left(\mathrm{h}^{2} \mathrm{~b}\right)$ was recorded for all characters except for days to first flowering $(27.76 \%)$ and days to $50 \%$ flowering $(34.67 \%)$ which have moderate values. Genetic advance in per cent of mean was high for all the characters except moderate for first flowering node $(12.88 \%)$, fruit length $(17.59 \%)$, fruit diameter $(13.99 \%)$ as well as low for days to first flowering $(1.69 \%)$ and days to $50 \%$ flowering $(2.28 \%)$. The higher value of genetic advance indicates that selection of genotypes on the basis of these characters is desirable. Fruit yield showed positive and highly significant (at $1 \%$ level of significance) genotypic association with fruit diameter, number of fruits per plant, average fruit weight and number of seeds per pod. The genotypes, viz. Kashi Kranti, Kashi Satdhari, VROB-159, Punjab-8 and Kashi Mohini were found promising for most of the yield contributing traits. These genotypes could be used further in hybrid breeding programme.
\end{abstract}

Keywords: Character association, Genotypes, Heritability, Okra, Variability, Yield

\section{INTRODUCTION}

Okra (Abelmoschus esculentus L. Moench) commonly known as lady's finger and it belongs to the family Malvaceae. . It is one of the oldest cultivated vegetable crops and at present it is one of the most important vegetable crop cultivated in tropical, sub-tropical and warm temperate regions of the world.

However, okra is widely distributed from Africa to Asia, southern Europe and America (Ariyo, 1993). In world, India rank first in okra production with $72.9 \%$ share in world okra production and produces okra in an area of 532.7 thousand hectares with production of 6346.4 thousand tonnes and productivity of 11.9 tonnes/ ha (Anonymous, 2015). Highest productivity is reported from Ghana (20.0 tonnes/ha) followed by Egypt (14.0 tonnes/ha). In India, West Bengal (14\% share) is leading okra producer in the country followed by Bihar (12\% share), Gujarat (12\% share), Andhra Pradesh (10\% share) and Odisha (9\% share). In Bihar okra is grown in an area of 58.08 thousand hectares with production of 783.54 thousand million tonnes and productivity of 13.5 tonnes/ ha (Anonymous, 2015).In any crop phenotypic and genotypic coefficients of var- iations are useful in detecting the amounts of variability present in the genotypes. Greater the variability and diversity in the population, more the chances of effective selection for the desirable plant types (Vavilov, 1951).

Okra belongs to the family Malvaceae and having significant variation in chromosome number and ploidy level in different species under the genus Abelmoschus. In okra the species Abelmoschus angulosus, has lowest number of chromosomes, $(2 \mathrm{n}=56)$, while in the species Abelmoschus caillie has highest chromosomes number $(2 \mathrm{n}=200)$ (Singh and Bhatnagar,1975). The cultivated species of okra have somatic chromosome number of 130. Okra appears to have originated in South Africa or Asia as reported by Thompson and Kelley (1957). Genetic variability/ diversity is utmost important component of plant breeding which is a major tool being used to cope with the ever-increasing pressure of an expanding world population on food production (Ariyo, 1990). The high yielding varieties of okra has been primarily developed by exploiting the genetic diversity available in the crop. This information on the nature and degree of genetic divergence is essential for the breeders to choose the promising 


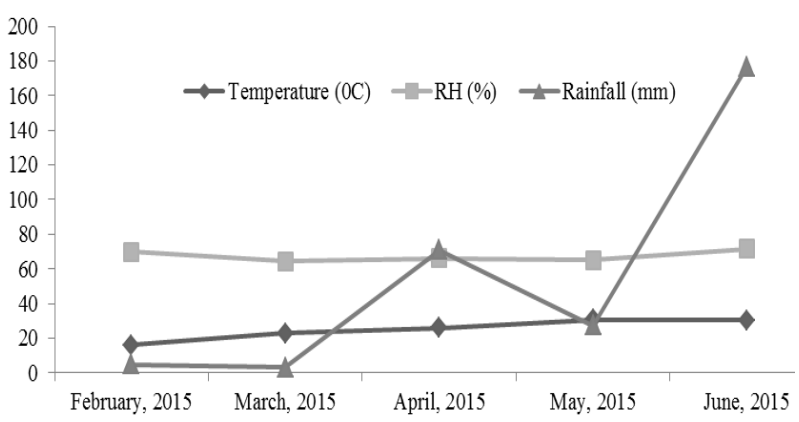

Fig. 1. Meteorological data recorded during crop growing season, 2015-16.

parents for purposeful hybridization in heterosis breeding and in order to benefit transgressive segregations (Khodadabi, 2011).As per the view of Ariyo (1993), vegetative traits of okra are positively correlated with yield and thus traits such as fruit size must be given prime attention in the selection of okra species for breeding programmes to improve yield. Moreover, the average weight and number of fruits/plant have been consistently identified as critical determinants of fruit yield (Saifullah and Rabbani, 2009).As we know that India is the richest country for diverse genotypes of okra. Geographically separation, genetic barriers to crossability, and different parents of evolution are the main reason of genetic diversity (Kumar et al. 2015). As well as success of the hybridization followed by selection depends largely on the selection of parents with high genetic diversity for traits of interest (Solankey el al., 2013). The present investigation therefore undertaken to evaluate genetic diversity among the 20 okra genotypes to find out promising genotypes for different traits for enhancing the fruit yield.

\section{MATERIALS AND METHODS}

The experiment was conducted using 20 okra genotypes including 4 checks i.e. Kashi Pragati (VRO 6), Kashi Kranti (VRO-22), Kashi Lalima and Arka Anamika collected from Indian Institute of Vegetable Research (IIVR), Varanasi and Indian Institute of Horticulture Research (IIHR), Bengaluru. They were evaluated in a randomized complete block design at Department of Horticulture (Vegetable and Floriculture), Bihar Agricultural University (B.A.U.), Sabour, Bhagalpur (Bihar), during summer season, 2015 - 16. This place comes under subtropical region and it is slightly semi-arid in nature and is characterized by dry summer, moderate rainfall and cold winter. The rainfall of this region is mainly distributed between middle of June to middle of October. The meteorological observations of present investigation were collected from the Meteorological unit of the Department of Agronomy, B.A.U., Sabour. The total rainfall received during the crop period was $282.57 \mathrm{~mm}$. The maximum temperature ranged from $23.9^{\circ} \mathrm{C}-35^{\circ} \mathrm{C}$ during the plant growth and development phase (Fig.1).

The recommended package of cultural practices was adopted for raising the crop (Fageria et al., 2003). Observations were recorded on 22 economically important traits (13 quantitative), viz. days to $50 \%$ flowering, first flowering node, plant canopy width $(\mathrm{cm})$, number of primary branches per plant, plant height $(\mathrm{cm})$, fruit length $(\mathrm{cm})$, fruit diameter $(\mathrm{cm})$,number of fruits per plant, average fruit weight $(\mathrm{g})$,number of seeds per pod, yield per plant $(\mathrm{kg})$, fruit yield $(\mathrm{q} / \mathrm{ha})$ and (9 qualitative traits)fruit: number of ridges $(5,6,7$, 8), leaf blade: depth of lobbing (shallow, medium, deep), fruit: constriction of basal part (absent, weak,

Table 1. Specific qualitative morphological traits of 20 okra genotype.

\begin{tabular}{cll}
\hline Sl. No. & Genotypes & Specific qualitative morphological traits \\
\hline 1 & BO-13 & Five ridges, green fruited, medium fruit pubescence and yellow petal colour \\
2 & Pusa Makhmali & Five ridges, light green fruited, weak fruit pubescence and yellow petal colour \\
3 & VRO-6 & Five ridges, green fruited, medium fruit pubescence and yellow petal colour \\
4 & Kashi Mohini & Five ridges, light green fruited, medium fruit pubescence and yellow petal colour \\
5 & Pusa Sawani & Five ridges, light green fruited, weak fruit pubescence and yellow petal colour \\
6 & Punjab-8 & Five ridges, green fruited, medium fruit pubescence and yellow petal colour \\
7 & Kashi Lalima & Five ridges, red fruited, medium fruit pubescence and red petal colour \\
8 & VROB-159 & Five ridges, red fruited, medium fruit pubescence and red petal colour \\
9 & SB-2 & Five ridges, light green fruited, medium fruit pubescence and yellow petal colour \\
10 & 307-10-1 & Five ridges, green fruited, medium fruit pubescence and yellow petal colour \\
11 & Kashi Kranti & Five ridges, dark green fruited, weak fruit pubescence and yellow petal colour \\
12 & Kashi Satdhari & Seven ridges, green fruited, strong fruit pubescence and yellow petal colour \\
13 & CO-3 & Five ridges, green fruited, medium fruit pubescence and yellow petal colour \\
14 & IC-14909 & Five ridges, light green fruited, medium fruit pubescence and yellow petal colour \\
15 & VROB-178 & Five ridges, green fruited, medium fruit pubescence and yellow petal colour \\
16 & Arka Anamika & Five ridges, light green fruited, medium fruit pubescence and yellow petal colour \\
17 & IBS-02 & Five ridges, light green fruited, medium fruit pubescence and yellow petal colour \\
18 & VRO-109 & Five ridges, light green fruited, medium fruit pubescence and yellow petal colour \\
19 & Azad Bhindi-1 & Five ridges, green fruited, medium fruit pubescence and yellow petal colour \\
20 & VRO-106 & Five ridges, dark green fruited, medium fruit pubescence and yellow petal colour \\
\hline & &
\end{tabular}


Meenakshi Kumari et al. / J. Appl. \& Nat. Sci. 9 (3): 1825 -1830 (2017)

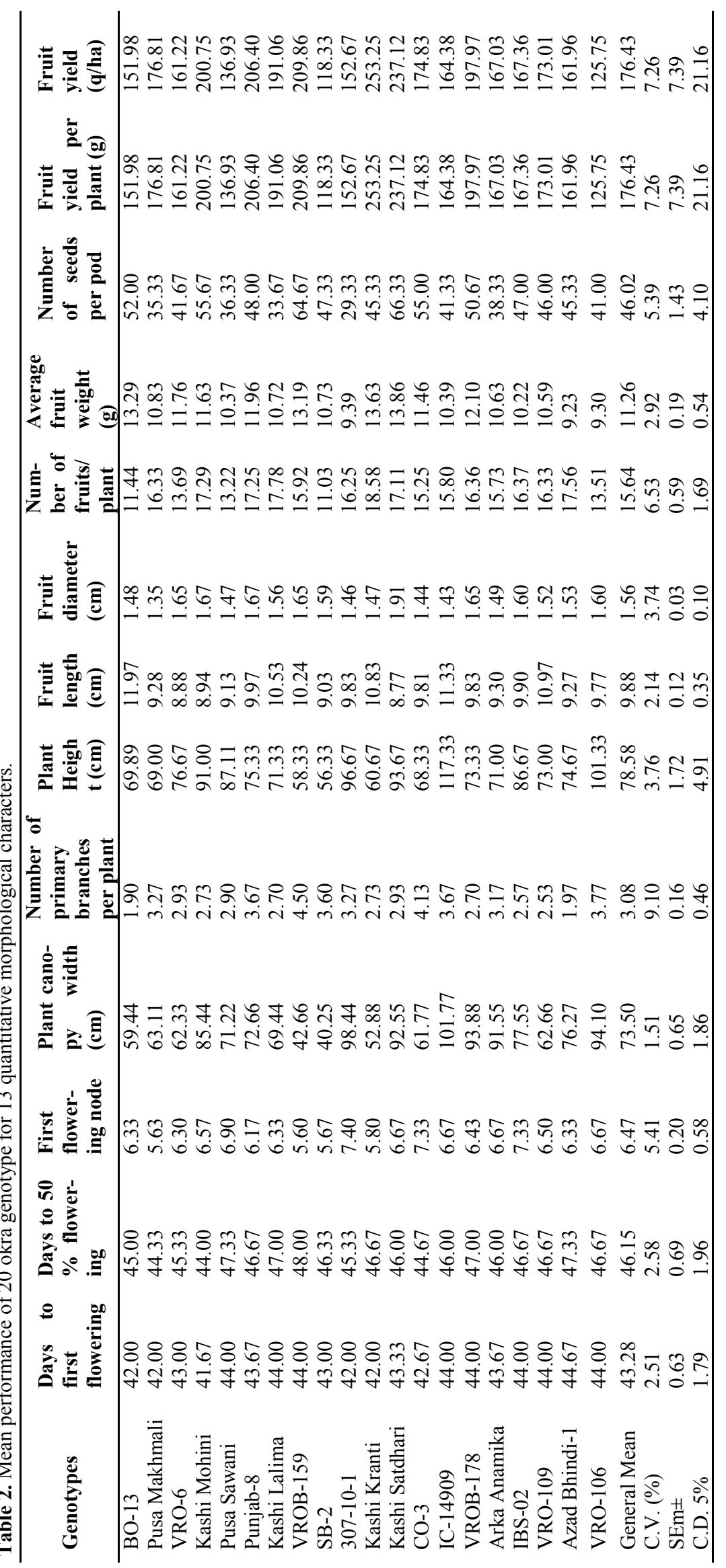


strong), fruit: shape of apex (narrow acute, acute, blunt), fruit colour (light green, green, light red, red, purple), flower petal colour (cream, yellow, purple), Flower petal base colour (inside only, both side), stem pubescence (absent, weak, medium, strong), fruit: pubescence (absent, weak, medium, strong). The soil of plot was sandy loam in texture having good fertility, properly leveled and well drained. Five plants in each genotype were selected randomly and were tagged and used for recording observations for the above characters. The morphological observations were taken with the help of Guidelines for the Conduct of Test for Distinctiveness, Uniformity and Stability (DUS) on okra by Protection of Plant Varieties and Farmers' Rights Authority (Plant Protection Variety and Farmers Right Authority), Government of India. Phenotypic and Genotypic variance was calculated as per the formula suggested by Comstock and Robinson (1948). The genotypic and phenotypic co-efficients of variation were calculated in accordance to the procedure outlined by Burton (1952). Heritability in broad sense was calculated as per the formula suggested by Burton and Devane (1953) moreover, genetic advance by Johnson et al. (1955). Phenotypic and genotypic correlation coefficients were calculated as per formula suggested by AlJibouri et al. (1956).

\section{RESULTS AND DISCUSSION}

In the present study a wide range of variation in mean performance of genotypes were observed for all the characters. There was uniform yellow petal colour for all genotypes expect Kashi Lalima and VROB-159 i.e. red petal colour as well as these genotypes have red fruit colour while rest of the genotypes have green fruit colour (Table 1).

The genotype, Kashi Kranti, gave significantly highest yield per plant $(253.25 \mathrm{~g}$ ), compared to other okra genotypes (Table 2 and 3 ). The earliest flowering (days to first flowering and days to $50 \%$ flowering) was observed in the variety Kashi Mohini. However, VROB159 has lowest value for the first flowering node which is at par with the genotypes, Pusa Makhmali, Punjab-8, SB-2 and Kashi Kranti. The phenotypic coefficient of variation (PCV) for all characters was higher than the genotypic coefficient of variation (GCV). Kumar et al. (2015) also reported higher PCV (26.25\%) than GCV $(23.71 \%)$ for fruit yield in okra. Similar trend for GCV and PCV was also reported by Koundinya et al. (2013) and Khajuria (2016). In present study, the phenotypic coefficient of variation ranged from $2.95 \%$ (days to first flowering) to $27.13 \%$ (Plant canopy width). The phenotypic coefficient of variability expressed in terms of percentage was comparatively high for plant canopy width, number of primary branches per plant, plant height, number of seeds per pod, fruit yield per plant; moderate for number of fruits/ plant and average fruit weight; moreover, low for days to first flowering, days to $50 \%$ flowering, first flowering node, fruit length and fruit diameter (Table 2). Kumar et al. (2015) also reported low PCV for days to first flowering, days to $50 \%$ flowering and moderate for number of branches, number of fruits and fruit yield in okra. In any crop species, higher the coefficient of genetic variation greater will be the chances of improvement in that character.

In this study genotypic coefficient of variation was higher for plant canopy width. However, moderate value of PCV and GCV was observed for plant height $(\mathrm{PCV}=21.60 \%, \mathrm{GCV}=21.27 \%)$.

Bagwale et al. (2016) found highest PCV for number of branches (69.72) followed by fruit yield per plant (46.17). While moderate PCV was observed for traits plant height (27.30) while lowest PCV was observed in number of seeds per fruit (dry fruit) (11.76), length of fruit (9.49), girth of fruit (8.28), number of ridges on fruit (9.36), days to initiation of flowering (6.68) and days to $50 \%$ flowering (6.60).The similar results in

Table 3. Estimates of variability parameters for 13 characters in okra.

\begin{tabular}{|c|c|c|c|c|c|c|c|}
\hline \multirow{2}{*}{ Characters } & \multirow{2}{*}{$\begin{array}{l}\text { General } \\
\text { Mean }\end{array}$} & \multicolumn{2}{|c|}{ Range } & \multirow{2}{*}{ GCV (\%) } & \multirow{2}{*}{$\operatorname{PCV}(\%)$} & \multirow{2}{*}{$h^{2} b(\%)$} & \multirow{2}{*}{$\begin{array}{l}\text { G.A. \% of } \\
\text { Mean (5\%) }\end{array}$} \\
\hline & & Lowest & Highest & & & & \\
\hline Days to first flowering & 43.28 & 41.67 (Kashi Mohi- & 44.67 (Azad & 1.55 & 2.95 & 27.76 & 1.69 \\
\hline Days to $50 \%$ flowering & 46.15 & 44.00 Kashi Mohini & 48.00 VROB-159 & 1.88 & 3.19 & 34.67 & 2.28 \\
\hline First flowering node & 6.47 & 5.60 VROB- 159 & $7.40(307-10-1)$ & 7.66 & 9.38 & 66.69 & 12.88 \\
\hline Plant canopy width (cm) & 73.50 & $40.25 \mathrm{SB}-2$ & 101.77 IC-14909 & 27.09 & 27.13 & 99.69 & 55.72 \\
\hline $\begin{array}{l}\text { Number of primary } \\
\text { branches per plant }\end{array}$ & 3 & 1 & 4 & 0 & 22.86 & 8 & 39.63 \\
\hline Plant Height (cm) & 78.58 & $56.33 \mathrm{SB}-2$ & 117.33 (IC-14909) & 21.27 & 21.60 & 96.97 & 43.15 \\
\hline Fruit length $(\mathrm{cm})$ & 9.88 & 8.77 Kashi Satdhari & $11.97 \mathrm{BO}-13$ & 8.79 & 9.04 & 94.41 & 17.59 \\
\hline Fruit diameter $(\mathrm{cm})$ & 1.56 & 1.35Pusa Makhmali & 1.91 Kashi Satdhari & 7.58 & 8.45 & 80.38 & 13.99 \\
\hline Number of fruits/ plant & 15.64 & $11.03 \mathrm{SB}-2$ & 18.58 Kashi Kranti & 12.58 & 14.17 & 78.77 & 22.99 \\
\hline Average fruit weight (g) & 11.26 & 9.23 Azad Bhindi-1 & 13.86 Kashi Satdhari & 12.37 & 12.70 & 94.72 & 24.79 \\
\hline Number of seeds per pod & 46.02 & $29.33(307-10-1)$ & 66.33 (Kashi Satdhari) & 20.70 & 21.39 & 93.64 & 41.27 \\
\hline Fruit yield per plant (g) & 176.43 & 118.33 SB-2 & 253.25 Kashi Kranti & 18.96 & 20.30 & 87.23 & 36.49 \\
\hline Fruit yield (q/ha) & 176.43 & $118.33 \mathrm{SB}-2$ & 253.25 Kashi Kranti & 18.96 & 20.30 & 87.23 & 36.49 \\
\hline
\end{tabular}


Table 4. Phenotypic (rp) and genotypic (rg) correlation coefficients for 13 characters in 20 okra genotypes.

\begin{tabular}{|c|c|c|c|c|c|c|c|c|c|c|c|c|c|}
\hline $\begin{array}{l}\text { Charac- } \\
\text { ters }\end{array}$ & DF & D50\%F & FFN & PCW & PBPP & PH & FL & FD & FPP & AFW & NSPP & YPP & FY \\
\hline \multirow{2}{*}{ DFF } & $\mathrm{rp}$ & $0.804 * *$ & 0.162 & 0.144 & 0.075 & 0.128 & 0.012 & 0.165 & 0.057 & -0.187 & 0.018 & -0.074 & -0.074 \\
\hline & $\mathrm{rg}$ & $0.784 * *$ & -0.007 & $0.283^{*}$ & 0.012 & 0.178 & -0.035 & $0.273^{*}$ & 0.111 & $-0.520 * *$ & -0.011 & $-0.262 *$ & $-0.262 *$ \\
\hline \multirow{2}{*}{$D 50 \% F$} & & $\mathrm{rp}$ & -0.024 & -0.075 & 0.089 & -0.081 & 0.118 & 0.182 & 0.113 & -0.004 & 0.069 & 0.094 & 0.094 \\
\hline & & $\mathrm{rg}$ & $-0.295 * *$ & -0.125 & -0.011 & -0.184 & 0.146 & $0.286^{*}$ & 0.110 & -0.099 & 0.059 & 0.034 & 0.034 \\
\hline \multirow{2}{*}{ FFN } & & & $\mathrm{rp}$ & $0.505^{* *}$ & -0.108 & $0.486^{* *}$ & -0.044 & -0.091 & 0.044 & $-0.342 * *$ & -0.145 & -0.193 & -0.193 \\
\hline & & & $\mathrm{rg}$ & $0.617 * *$ & -0.076 & $0.598 * *$ & -0.055 & -0.027 & 0.024 & $-0.441 * *$ & -0.185 & $-0.285^{*}$ & $-0.285^{*}$ \\
\hline \multirow{2}{*}{ PCW } & & & & $\mathrm{rp}$ & -0.046 & $0.851 * *$ & -0.035 & 0.078 & $0.216^{*}$ & $-0.364 * *$ & $-0.226^{*}$ & -0.073 & -0.073 \\
\hline & & & & $\mathrm{rg}$ & -0.043 & $0.869 * *$ & -0.035 & 0.081 & $0.247 *$ & $-0.376^{* *}$ & $-0.238^{*}$ & -0.077 & -0.077 \\
\hline \multirow{2}{*}{ PBPP } & & & & & $\mathrm{rp}$ & 0.050 & -0.118 & 0.034 & -0.024 & 0.015 & 0.127 & 0.028 & 0.028 \\
\hline & & & & & rg & 0.036 & -0.149 & -0.002 & -0.152 & 0.005 & 0.162 & -0.056 & -0.056 \\
\hline \multirow{2}{*}{ PH } & & & & & & $\mathrm{rp}$ & 0.053 & 0.048 & 0.083 & $-0.354 * *$ & -0.189 & -0.158 & -0.158 \\
\hline & & & & & & $\mathrm{rg}$ & 0.046 & 0.049 & 0.056 & $-0.373 * *$ & -0.197 & -0.200 & -0.200 \\
\hline \multirow{2}{*}{ FL } & & & & & & & $\mathrm{rp}$ & $-0.337 * *$ & -0.002 & 0.195 & -0.027 & 0.093 & 0.093 \\
\hline & & & & & & & rg & $-0.413 * *$ & -0.012 & 0.185 & -0.039 & 0.081 & 0.081 \\
\hline \multirow{2}{*}{ FD } & & & & & & & & $\mathrm{rp}$ & 0.140 & $0.426 * *$ & $0.568 * *$ & $0.386 * *$ & $0.386 * *$ \\
\hline & & & & & & & & rg & 0.117 & $0.423 * *$ & $0.684 * *$ & $0.379 * *$ & $0.379 * *$ \\
\hline \multirow{2}{*}{ FPP } & & & & & & & & & $\mathrm{rp}$ & 0.084 & 0.023 & $0.770 * *$ & $0.770 * *$ \\
\hline & & & & & & & & & $\mathrm{rg}$ & 0.094 & 0.060 & $0.747 * *$ & $0.747 * *$ \\
\hline \multirow{2}{*}{ AFW } & & & & & & & & & & $\mathrm{rp}$ & $0.658 * *$ & $0.694^{* *}$ & $0.694 * *$ \\
\hline & & & & & & & & & & $\mathrm{rg}$ & $0.706 * *$ & $0.726 * *$ & $0.726 * *$ \\
\hline \multirow{2}{*}{ NSPP } & & & & & & & & & & & $\mathrm{rp}$ & $0.434 * *$ & $0.434 * *$ \\
\hline & & & & & & & & & & & $\mathrm{rg}$ & $0.504 * *$ & $0.504 * *$ \\
\hline \multirow{2}{*}{ YPP } & & & & & & & & & & & & $\mathrm{rp}$ & $1.000 * *$ \\
\hline & & & & & & & & & & & & $\mathrm{rg}$ & $1.000 * *$ \\
\hline \multirow[t]{2}{*}{ FY } & & & & & & & & & & & & & $\mathrm{rp}$ \\
\hline & & & & & & & & & & & & & $\mathrm{rg}$ \\
\hline
\end{tabular}

*, ** Significant at $5 \%$ and $1 \%$ probability level, respectively. Where, DFF=Days to first flowering, D50\% $\mathrm{F}=\mathrm{Days}$ to $50 \%$ flowering, FFN=First flowering node, $\mathrm{PCW}=$ Plant canopy width $(\mathrm{cm}), \mathrm{PBPP}=$ Number of primary branches per plant, $\mathrm{PH}=\mathrm{Plant}$ Height $(\mathrm{cm}), \mathrm{FL}=$ Fruit length $(\mathrm{cm}), \mathrm{FD}=$ Fruit diameter $(\mathrm{cm}), \mathrm{FPP}=$ Number of fruits/ plant, $\mathrm{AFW}=$ Average fruit weight $(\mathrm{g})$, $\mathrm{NSPP}=$ Number of seeds per pod, YPP $=$ Fruit yield per plant $(\mathrm{g}), \mathrm{FY}=$ Fruit yield $(\mathrm{q} / \mathrm{ha})$.

okra were also described by other workers (Dhall et al., 2003; Singh et al., 2006; Jaiprakashnarayan et al., 2006, Yadav et al., 2010 and Koundinya et al., 2013).

High heritability estimates coupled with high genetic advancement in per cent of mean were observed for plant canopy width, plant height, number of seeds per pod and for fruit yield per plant (Table 3). This indicates substantial contribution of additive genetic variance for these characters. These results are in consonance with the earlier workers (Indurani and Veeraragavanthatham, 2005; Mehta et al., 2006; Karri and Acharyya, 2012; Koundinya et al., 2013). Therefore, improvement in these traits would be more effective by selection.

The correlation studies indicate that days to first flowering have positive and highly significant association with days to $50 \%$ flowering $(\mathrm{rp}=0.804, \mathrm{rg}=0.784$ ) (Table 4). First flowering node exerted positive and highly significant association with plant canopy width $(\mathrm{rp}=0.505, \mathrm{rg}=0.617)$ and plant height $(\mathrm{rp}=0.486, \mathrm{rg}=$ $0.598)$ while, negative and highly significant association with average fruit weight ( $\mathrm{rp}=-0.342, \mathrm{rg}=-0.441$ ). Plant canopy width expressed positive and highly significant association with plant height ( $\mathrm{rp}=0.851, \mathrm{rg}=$ 0.869 ). Fruit diameter have positive and highly signifi- cant association with average fruit weight $(\mathrm{rp}=0.426$, $\mathrm{rg}=0.423$ ), number of seeds per pod ( $\mathrm{rp}=0.568, \mathrm{rg}=$ 0.684 ). Average fruit weight have positive and highly significant association with number of seeds per pod $(\mathrm{rp}=0.658, \mathrm{rg}=0.706)$. Plant height have negative and highly significant association with average fruit weight $(\mathrm{rp}=-0.354, \mathrm{rg}=-0.373)$. Similar pattern of correlation in okra were also reported by Balai et al. (2014), Solankey et al. (2014), Ahamed (2015) and Binalfew and Alemu (2016). Fruit yield showed positive and significant association with fruit diameter, number of fruits per plant, average fruit weight, number of seeds per pod. These findings of character association are in close conformity with the findings of Balai et al. (2014) and Binalfew and Alemu (2016).

\section{Conclusion}

The variability parameters of the present study indicate that optimum variability was present in the research work. On the basis of performance the genotype Kashi Kranti was the best performer for most of the morphological quantitative traits followed by Kashi Satdhari. Likewise, VROB-159, Punjab-8 and Kashi Mohinialso showed better performance. Fruit yield showed positive and significant 
association with fruit diameter, number of fruits per plant, average fruit weight, number of seeds per pod and first flowering node. These characters and genotypes can be very much useful in future hybrid breeding programme of okra for higher yield and quality.

\section{ACKNOWLEDGEMENTS}

Authors acknowledge Bihar Agricultural University, Sabour, Bhagalpur (Bihar) for providing the research facility. The authors are also thankful to Director, IIVR, Varanasi and Director, IIHR, Bengaluru for the provision of okra germplasm used in this study. This article bears the BAU Communication no.: 249/2017.

\section{REFERENCES}

Ahamed, K.U., Akter, B., Ara, N., Hossain, M.F. and Moniruzzaman, M. (2015). Heritability, correlation and path coefficient analysis in fifty seven okra genotypes. Intel. J. Appl. Sci. and Biotech., 3(1):127-133

Al-jibouri, H. A., Miller, R. A. and Robinson, H. F. (1956). Genotypic and environmental variance in an upland cotton cross of interspecific origin. Agron. J., 50:633637

Anonymous (2015). Indian Horticulture Database. National Horticulture Board, Ministry of Agriculture, Government of India, Gurgaon, U.P., India

Ariyo, O.J. (1990). Variation and heritability of fifteen characters in okra (Abelmoschus esculentus (L.) Moench) Trop. Agric., 67(3) : 213-216

Ariyo, O.J. (1993). Genetic diversity in West African okra (Abelmoschu scaillei) (A. chev.) Stevels - Multivariate analysis of morphological and agronomic characteristics. Genetics Res. and Crop Evol., 40 : 25-32

Bagwale, S.B., Jawale, L.N., Deosarkar, D.B. and Jadhav, R.A. (2016). Genetic variability studies for yield, yield contributing and quality traits in okra [Abelmoschus esculentus (L.) Moench.]. Indian J. Agric. Res., 50(6) : 614-618

Balai, T.C., Maurya, I. B., Verma, S., and Kumar N. (2014). Correlation and path analysis in genotypes of okra [Abelmoschus esculentus (L.) Moench]. The Bioscan., 9 (2) : 799-802

Binalfew, T. and Alemu, Y. (2016). Characterization of okra (Abelmoschus esculentus L. Moench) germplasms collected from Western Ethiopia. Intel. J. Res. in Agri. and For., 3(2) : 11-17

Burton, G.W. (1952). Quantitative inheritance in grasses. Pro. $6^{\text {th }}$.Int.Grassland cong., $1: 277-283$

Burton, G.W. and Devane, E.W. (1953). Estimating heritability in all fescue (Fescutaca arundinancea) from replicated clonal materials. Agron. J., 45 : 478-481

Comstock, R.E. and Robinson, H.R. (1948). The component of genetic variance in population of biaparental progenies and their use in estimating the average of dominance. Biometr., 4:254-266

Dhall, R.K., Arora, S.K. and Rani, M. (2003). Studies on variability, heritability and genetic advance of advancedgeneration in okra [Abelmoschus esculentus (L.) Moench]. J. Res. Punjab Agric. Univ., 40:54-58

Fageria, M. S., Choudhary, B. R. and Dhaka, R. S. 2003. Vegetable Crops: Production Technology. Kalyani
Publishers, New Delhi

Indurani, C. and Veeraragavanthatham, D. (2005). Genetic variability, heritability and genetic advance in okra (Abelmoschus esculentus L. Moench.). Indian J. Hort., 62:303-305

Jaiprakashnarayan, R.P., Mulge, R., Kotikal, Y.K., Patil, M.P., Madalageri, M.B. and Patil, B.R. (2006). Studies ongenetic variability for growth and earliness characters in okra [Abelmoschus esculentus (L.) Moench.]. Crop Res., 32:411-413

Johnson, H.W., Rabinson, H.F. and Comstock, R.E. (1955). Estimate of genetic and environmental variability in soybean. Agron. J., $47: 314-318$

Karri, S.R. and Acharyya, P. (2012). Performance of okra [Abelmoschus esculentus (L.) Moench] cultivars under summer and rainy environments. Intel. J. Adv. Life Sci., $2: 17-26$

Khajuria, R.K., Sharma'J.P., Samnotra'R.K., Kumar'S. and Kaki,R. (2016).Variability studies in okra (Abelmoschus esculentus L. Moench). Green Farm., 7(2) : 266-271

Khodadabi, M., Fotokian, M.H. and Miransari, M. (2011). Genetic diversity of wheat genotypes based on cluster and principal component analyses for breeding strategies. Austr. J. Crop Sci., 5(1) : 17-24

Koundinya, A.V.V., Dhankhar, S.K. and Yadav, A.C. (2013). Genetic variability and divergence in okra (Abelmoschus esculentus). Indian J. Agric. Sci., 83 : 685-688

Kumar, A., Verma, R.B., Solankey, S.S. and Adarsh, A. (2015). Appraisal of okra (Abelmoschus esculentus L. Moench) genotypes for yield and yellow vein mosaic virus incidence. Indian Phytopath., 68(2):201-206

Mehta, D.R., Dhaduk, L.K., and Patel, K.D. (2006). Genetic variability, correlation and path co-efficient analysis studiesin okra [Abelmoschus esculentus (L.) Moench.]. Agric. Sci. Digest., $26: 15-18$

Saifullah, M. and Rabbani, M.G. (2009). Evaluation and characterization of okra (Abelmoschus esculentus L. Moench.) genotypes. SAARC J. Agri., 7(1) : 92-99

Singh, B., Pal, A.K. and Singh, S. (2006). Genetic variability and correlation analysis in okra [Abelmoschus esculentusL. Moench.]. Indian J. Horti. 63(3) : 281-285

Singh, H.B. and Bhatnagar, A. (1975). Chromosome number in an okra from Ghana. Indian J. Genet. Pl. Br., 36:2627

Solankey, S.S., Akhtar, S., Kumar, R., Verma, R.B. and Sahajanand, K. (2014). Seasonal response of okra (Abelmoschus esculentus L. Moench) genotypes for okra yellow vein mosaic virus incidence. Afr. J. Biotech., 13 : 1336-1342

Solankey, S.S., Singh, A. K. and Singh, R. K. (2013). Genetic expression of heterosis for yield and quality traits during different growing seasons in okra (Abelmoschus esculentus). Indian J. Agril., Sci.83 (8): 17-21

Thompson, C.H. and Kelley, C.W. (1957). Vegetable crops. McGraw Hill Book Co., Inc., USA

Vavilov, N.I. (1951). Origin variation immunity and breeding of cultivated plants chronica botanica, an international collection of studies in the method and history of biological and agriculture. Edited by Fransver Doorn. 13 No.11/6

Yadav, M., Chourasia, P.C., Singh, D.B. and Singh, G.K. (2010). Genetic variability, correlation coefficient and path analysis in okra. Indian J. Hort., 67 : 456-460 